\title{
Effect of air pollution on the prevalence of asthma and allergy: lessons from the German reunification
}

An increase in the prevalence of bronchial asthma has been reported in many countries, ${ }^{12}$ but there is still no conclusive explanation for these observations. The possible contribution of air pollution to atopy and bronchial asthma has gained increasing attention in recent years, and this topic has been addressed in several extensive reviews. ${ }^{3-7}$ Many detailed experimental and epidemiological reports are now available which have focused on the effects of sulphur dioxide $\left(\mathrm{SO}_{2}\right)$, airborne particulates, nitrogen dioxide $\left(\mathrm{NO}_{2}\right)$, and ozone on the airways of asthmatic subjects and normal populations. We will briefly summarise the effects of these pollutants on respiratory health to improve the understanding of the epidemiological data that have become available following the German reunification. Reunification offered the opportunity to compare two populations that have been exposed to highly different levels of air pollution.

Several controlled exposure studies have shown that asthmatic subjects are more sensitive to the bronchoconstrictor potency of $\mathrm{SO}_{2}$ than are healthy subjects. Bronchoconstriction can occur in some asthmatic individuals $^{8}$ during exercise at concentrations as low as $700 \mu \mathrm{g} / \mathrm{m}^{3}$ and is observed in many ${ }^{9}$ at about $1400 \mu \mathrm{g} / \mathrm{m}^{3}$. In contrast, healthy volunteers ${ }^{10}$ do not experience bronchoconstriction below concentrations of about $2700 \mu \mathrm{g} / \mathrm{m}^{3}$. Pollution episodes in the Meuse valley (Belgium) in 1930, in Donora (USA) in 1948, and in London in 1952 demonstrated detrimental effects on respiratory mortality related to high levels of $\mathrm{SO}_{2}$ (daily average about $4000 \mu \mathrm{g} / \mathrm{m}^{3}$ ), acid aerosols, and smoke. This was particularly true for patients with pre-existing asthma (in Meuse and Donora) or bronchitis and asthma (London). Several epidemiological investigations have confirmed the positive association between respiratory morbidity and $\mathrm{SO}_{2}$ or particulate matter at much lower levels in both adults and children. For example, a positive relationship between wheeze, peak flow impairment, and bronchodilator use on the one hand, and $\mathrm{SO}_{2}$ levels (highest daily average, $105 \mu \mathrm{g} / \mathrm{m}^{3}$ ), smoke (range 2$120 \mu \mathrm{g} / \mathrm{m}^{3}$ ), and particulate matter on the other, has recently been found in children with chronic respiratory symptoms. ${ }^{11}$ Even moderately elevated concentrations of $\mathrm{SO}_{2}$ and particulate matter during winter time may therefore have an impact on respiratory diseases in susceptible populations.

Much experimental and epidemiological work has also been performed on the respiratory effects of $\mathrm{NO}_{2}$. At concentrations of $200-500 \mu \mathrm{g} / \mathrm{m}^{3}$ this pollutant has been shown to cause an increase in bronchial responsiveness to external stimuli in some subjects with asthma, ${ }^{12-15}$ although other authors were unable to detect such effects at these ${ }^{16}$ or much higher concentrations. ${ }^{17}$ Similarly, in healthy subjects an increase in airway responsiveness has been observed at about $4000 \mu \mathrm{g} / \mathrm{m}^{3} \mathrm{NO}_{2}$ by some ${ }^{18}$ but not by others. No consistent effects on airway tone have been reported at these or lower concentrations. ${ }^{19}$ Several cross sectional studies have revealed a higher prevalence of respiratory symptoms in children and adults from homes where gas was used for cooking (implying peak $\mathrm{NO}_{2}$ levels of $400-800 \mu \mathrm{g} / \mathrm{m}^{3}$ ), suggesting an effect of indoor $\mathrm{NO}_{2}$ on respiratory health. ${ }^{20}$ In addition, an association between the annual average concentration of $\mathrm{NO}_{2}$
(11-51 $\left.\mu \mathrm{g} / \mathrm{m}^{3}\right)$ and the duration of symptomatic respiratory episodes has been reported in a random sample of preschool children. ${ }^{21}$ At present, however, studies do not permit unique conclusions to be drawn on the role of $\mathrm{NO}_{2}$, nor do they clearly indicate whether subjects with asthma are more susceptible to the adverse effects of $\mathrm{NO}_{2}$ than normal subjects.

In experimental settings ozone has been shown to cause impairment of lung function at levels of 160 $240 \mu \mathrm{g} / \mathrm{m}^{3}$ during prolonged exercise ${ }^{22}$ whereas the effective concentrations during shorter exposures ${ }^{23}$ range between 400 and $800 \mu \mathrm{g} / \mathrm{m}^{3}$. The typical functional changes following exposure to ozone are a transient restrictive ventilatory impairment and an increase in bronchial responsiveness to methacholine and histamine. Only few data from controlled exposure studies in asthmatic subjects are available, ${ }^{24}$ some of them suggesting a slightly increased ozone sensitivity when compared with healthy individuals. ${ }^{25}$ In a large sample of subjects we found that interindividual variation in acute alterations of lung function and airway responsiveness after ozone breathing were much more pronounced than differences in response between healthy subjects and patients with rhinitis or asthma. ${ }^{26}$ Epidemiological studies have shown positive associations between respiratory illness and ambient ozone levels mainly in children, recent studies coming from Tennessee, ${ }^{27}$ California, ${ }^{28}$ Austria, ${ }^{29}$ and Mexico. ${ }^{30}$ They indicate that long term exposure to high ambient ozone concentrations $(45 \%$ of days $>120 \mu \mathrm{g} / \mathrm{m}^{3}$ ) may be associated with persistent bronchial hyperresponsiveness. ${ }^{29}$ Changes in lung function on a daily basis relate in a negative fashion to ambient ozone levels ${ }^{2830}$ and an individual response may ${ }^{30}$ or may not ${ }^{27}$ be dependent on pre-existing airway disease.

The German reunification in 1989 provided a challenging opportunity to study two genetically similar populations who, over more than 40 years, have been exposed to different levels of environmental pollution as well as different living conditions. The East German industralised areas, especially in Saxony and Thuringia, are characterised by high concentrations of $\mathrm{SO}_{2}$ and particulate matter - for example, average monthly levels of $\mathrm{SO}_{2}$ and particulate matter in Leipzig and Erfurt (East Germany) during winter were about $300 \mu \mathrm{g} / \mathrm{m}^{3}$ and $120 \mu \mathrm{g} / \mathrm{m}^{3}$, respectively, whereas the values in a moderately industralised city in West Germany such as Munich were always below $50 \mu \mathrm{g} / \mathrm{m}^{3}\left(\mathrm{SO}_{2}\right)$ and $80 \mu \mathrm{g} / \mathrm{m}^{3}$ (particulate matter). Conversely, $\mathrm{NO}_{2}$ levels tended to be higher in the West German than in the East German cities. Several investigations are still under way and few data have yet been published in international journals; we will therefore briefly review the trends indicated by the available data.

Krämer and coworkers ${ }^{31}$ performed a cross sectional study on respiratory symptoms and doctors' diagnoses in more than 4000 preschool children in several towns in East and West Germany. First results indicate higher prevalences of "frequent cough" and lower prevalences of doctor diagnosed asthma and rhinitis in children from the East German cities than in children from West Germany. These findings are compatible with a recent study reported by von Mutius et $a l^{32}$ in which 
6081 children in Leipzig (East Germany) and Munich (West Germany) were asked for their lifetime prevalence of asthma and allergic disorders, and bronchial responsiveness was assessed by cold air inhalation challenge. The lifetime prevalence of doctor diagnosed asthma was $7.3 \%$ in Leipzig and $9.3 \%$ in Munich, and prevalence of wheezing was $20 \%$ and $17 \%$, respectively. The prevalence of diagnosed bronchitis was higher in Leipzig $(30.9 \%)$ than in Munich (15.9\%). No difference was found in the prevalence of bronchial hyperresponsiveness to cold air. Interestingly, hay fever $(2 \cdot 4 \% v 8.6 \%)$ and typical symptoms of rhinitis $(16.6 \% v 19 \cdot 7 \%)$ were reported less frequently in Leipzig than in Munich. In 7200 randomly selected subjects aged between 20 and 44 years in the two German centres of the EC Respiratory Health Survey-Erfurt (East Germany) and Hamburg (West Germany)-the answers to screening questions revealed a similar tendency. ${ }^{33}$ Of the subjects from Erfurt $1.3 \%$ reported an attack of asthma within the last year and $13.2 \%$ answered positively when asked whether they had suffered from nasal allergies such as hay fever. The respective figures for Hamburg were considerably higher at $3.0 \%$ and $22.8 \%$. These data will be compared with the results of lung function tests, methacholine challenges, skin tests, and specific IgE determinations. If one considers that the question on, for example, asthma has a specificity of $90 \%$ with respect to positive histamine challenge, ${ }^{34}$ our figures lend support to the perplexing impression that the true prevalence of asthma seems to be lower in East than in West Germany. The final evaluation will take into account the influences of individual risk factors such as smoking, occupational exposure, and other epidemiologically relevant predictors for respiratory disease.

An explanation remains to be found for the apparently higher prevalence of atopic and asthmatic disorders in West than in East Germany. Since asthma in children and adolescents is most often of atopic origin and is closely linked to bronchial hyperresponsiveness, the studies from East and West Germany suggest that long term exposure to high levels of $\mathrm{SO}_{2}$ and particulate matter does not increase the prevalence of asthma or allergy. Animal studies which have shown facilitated allergic sensitisation after low level $\mathrm{SO}_{2}$ exposure ${ }^{35}$ possibly do not adequately reflect the conditions met in human subjects.

The higher prevalence of allergic sensitisation in West Germany is further supported by the data on IgE antibodies against important indoor allergens such as Dermatophagoides pteronyssinus, $D$. farinae, and cat which have been obtained in 901 vocational pupils from Leuna (East Germany) and Duisburg (West Germany). The prevalence of antibodies against these mites and cat was more than fivefold and threefold, respectively, higher in Duisburg than in Leuna. ${ }^{36}$ No such differences were found in sensitisation against outdoor allergens such as rye, Timothy grass, birch, and mugwort. One may therefore speculate that "western" housing styles ${ }^{2}$ with decreased ventilation, higher humidity, and probably higher numbers of pets may be more important for the prevalence of asthma and atopy than "classical" outdoor pollutants such as $\mathrm{SO}_{2}$ and particulate matter. These speculations may also provide a clue to the extraordinarily high rates of asthma and atopy found in New Zealand, a country which also seems to have a perfect climate for allergens. If this line of reasoning is true, measures must be taken to reduce the indoor allergen burden and thereby decrease the risk of atopy and asthma. ${ }^{37}$ As an alternative explanation it is tempting to relate the increased prevalence of allergic disorders in Western cities to the much heavier traffic exhausts.
It has been hypothesised that the allergenicity of antigens could be enhanced by pollutants. Ishizaki and coworkers $^{38}$ found the highest incidence of cedar pollinosis among residents living along an intercity main road with heavy automobile traffic, whereas residents in the cedar forests with less automobile traffic showed a lower incidence. It is not clear, however, that confounding fac- $\stackrel{\vec{S}}{\stackrel{D}{+}}$ tors have been adequately taken into account. Krämer $\bar{C}$ and coworkers ${ }^{39}$ reported an elevated frequency of posi- $\frac{\bar{\sigma}}{\bar{n}}$ tive RAST classes to pollen allergen in those children $\frac{\sigma}{\sigma}$ exposed for more than one hour per day to traffic. Others $\stackrel{\Phi}{\unrhd}$ have reported a more frequent sensitisation to aeroallergens in polluted than in non-polluted regions, and speci- $\overrightarrow{0}$ fic IgE levels were higher in subjects from urban areas than in those from rural areas. ${ }^{40}$ It has recently been $\vec{\sigma}$ shown experimentally that short term inhalation of $\vec{F}$ $240 \mu \mathrm{g} / \mathrm{m}^{3}$ ozone tended to increase bronchial responsive- $\stackrel{x}{x}$ ness to inhaled allergens in a small group of asthmatic subjects. ${ }^{41}$ Such an effect has not been found at the level ${ }_{\infty}^{\infty}$ of the nose, ${ }^{42}$ suggesting different susceptibility or differ- $\bullet$ ent mechanisms at these levels. Although animal studies 옥 suggest that allergic sensitisation could be increased by previous exposure to ozone, ${ }^{4}$ this effect has not been con- $\phi$ sistently observed after long term exposure to high ozone $\frac{\vec{D}}{\Phi}$ concentrations. ${ }^{29}$

What can be learned from these studies? Asthmatic $\stackrel{\Phi}{\square}$ patients show increased susceptibility to the adverse res- $\vec{P}$ piratory health effects of most air pollutants. This is true for $\mathrm{SO}_{2}$ and probably, to a lesser extent, for $\mathrm{NO}_{2}$ and ozone. The question whether air pollution can cause 0 asthma and atopy is not yet resolved. Studies from East and West Germany suggest that $\mathrm{SO}_{2}$ and smoke do not increase allergic sensitisation under real life condi- $\frac{\circ}{\Phi}$ tions. ${ }^{31-33}$ If ozone exposure was a major risk factor for $\stackrel{2}{\Rightarrow}$ atopy and asthma a substantially higher rate of these dis- $\frac{0}{3}$ orders would be expected in cities like Los Angeles, which is not the case. Multicentre cross sectional studies? which cover a broad variety of risk factors for atopy and asthma such as the EC Respiratory Health Survey are으 therefore clearly warranted and will shed light on the still $\underset{x}{x}$ open question as to what extent indoor and outdoor fac- $\overline{3}$ tors are relevant for the prevalence and severity of these disorders. Skilful combination of epidemiological studies $\frac{\delta}{3}$ and controlled human exposure experiments seems to be more promising than further extension of data derived $\stackrel{5}{5}$ from laboratory animal studies.

H MAGNUSSEN R JÖRRES N Krankenhaus Grosshansdorf, Zentrum für Pneumologie und Thoraxchirurgie, N
LVA und HansestadtHamburg,
Germany ${ }^{\mathrm{C}}$
D NOWAK Zentrum für Pneumologie und Thoraxchirurgie, N
LVA und HansestadtHamburg,
Germany
D NOWAK Zentrum für Pneumologie und Thoraxchirurgie, N
LVA und HansestadtHamburg,
Germany ${ }^{\mathrm{C}}$
D NOWAK Department of Occupational Medicine, University of Hamburg,

Reprint requests to: Dr $\mathrm{H}$ Magnussen, Krankenhaus Grosshansdorf,

Wöhrendamm 80, D-22927 Grosshansdorf, Germany

Burney PGJ. Strategy for asthma. BMF 1991;303:571-3.

2 Woolcock AJ. Worldwide trends in asthma morbidity and mortality Explanation of trends. Bull Int Union Tuberc Lung Dis 1991;66:85-9.

Abramson M, Voigt T. Ambient air pollution and respiratory disease. Med 7 Aust 1991;154:543-53.

4 Molfino NA, Slutsky AS, Zamel N. The effects of air pollution on allergic bronchial responsiveness. Clin Exp Allergy 1992;22:667-72.

5 Pierson WE, Koenig JQ. Respiratory effects of air pollution on allergic disease. F Allergy Clin Immunol 1992;90:557-66.

6 Nowak D, Jörres R, Magnussen $H$. Einflu $\beta$ von Luftschadstoffen auf die Lungenfunktion. Atemwegs- und Lungenkrankheiten 1992;18:441-7.

7 Wardlaw AJ. The role of air pollution in asthma. Clin Exp Allergy 1993; 23:81-96.

8 Linn WS, Venet TG, Shamoo DA, Valencis LM, Anzar UT, Spier CE, et al. Respiratory effects of sulfur dioxide in freely breathing, heavily exercising asthmatics: a dose response study. Am Rev Respir Dis 1983; 127:278-83. 
9 Magnussen H, Jörres R, Wagner HM, von Nieding G. Relationship between the airway response to inhaled sulfur dioxide, isocapnic hyperventilation, and histamine in asthmatic subjects. Int Arch Occup Environ Health 1990;62:485-91.

10 Sheppard D, Wong WS, Uehara CF, Nadel JA, Boushey HA. Lower threshold and greater bronchomotor responsiveness of asthmatic subjects to sulfur dioxide. Am Rev Respir Dis 1980;122:873-8.

11 Roemer W, Hoek G, Brunekreef B. Effect of ambient winter air pollution on respiratory health of children with chronic respiratory symptoms. Am on respiratory health of children
Rev Respir Dis 1993;147:118-24.

12 Orehek J, Massari JP, Gayard P, Grimaud C, Charpin J. Effect of shortterm, low-level nitrogen dioxide exposure on bronchial sensitivity of asthmatic patients. $\mathcal{F}$ Clin Invest 1976;57:301-7.

13 Kleinman MT, Bailey RM, Linn WS, Anderson KR, Whynst JD, Shamoo $\mathrm{DA}$, et al. Effects of $0.2 \mathrm{ppm}$ nitrogen dioxide on pulmonary function and response to bronchoprovocation in asthmatics. $\mathcal{f}$ Toxicol Environ Health 1983;12:815-26.

14 Mohsenin V. Airway responses to nitrogen dioxide in asthmatic subjects. f Toxicol Environ Health 1987;22:371-80.

15 Jörres R, Magnussen $H$. Airways response of asthmatics after a $30 \mathrm{~min}$ exposure, at resting ventilation, to $0.25 \mathrm{ppm} \mathrm{NO}_{2}$ or $0.5 \mathrm{ppm} \mathrm{SO}_{2}$. Eur Respir F 1990;3:132-7.

16 Hazucha MJ, Ginsberg JF, McDonnell WF, Haak Jr ED, Pimmel RL, Abdul-Salaam S, et al. Effects of $0.1 \mathrm{ppm}$ nitrogen dioxide on airways of normal and asthmatic subjects. F Appl Physiol 1983;54:730-9.

17 Linn WS, Solmon JC, Trim SC, Spier CE, Shamoo DA, Venet TG, et al. Effects of exposure to $4 \mathrm{ppm}$ nitrogen dioxide in healthy and asthmatic Effects of exposure to 4 ppm nitrogen dioxide in
volunteers. Arch Environ Health 1985;40:234-9.

$18 \mathrm{Mohsenin} \mathrm{V}$. Airway responses to $2 \cdot 0 \mathrm{ppm}$ nitrogen dioxide in normal subjects. Arch Environ Health 1988;43:242-6.

19 Bylin G, Lindvall T, Rehn T, Sundin B. Effects of short term exposure to ambient nitrogen dioxide concentrations on human bronchial reactivity and lung function. Eur $\mathcal{F}$ Respir Dis 1985;66:205-17.

20 Samet JM, Marbury MC, Spengler JD. Health effects and sources of indoor air pollution. Part I. Am Rev Respir Dis 1987;136:1486-508.

21 Braun-Fahrländer C, Ackermann-Liebrich U, Schwartz J, Griehm HP Rutishauser M, Wanner HU. Air pollution and respiratory symptoms in preschool children. Am Rev Respir Dis 1992;145:42-7.

22 Horstman DH, Folinsbee LJ, Ives PJ, Abdul-Salaam S, McDonnell WF. Ozone concentration and pulmonary response relationships for 6.6hour exposures with five hours of moderate exercise to $0.08,0 \cdot 10$, and 0.12 ppm. Am Rev Respir Dis 1990;142:1158-63.

23 Dimeo JM, Glenn MG, Holtzman MJ, Sheller JR, Nadel JA, Boushey HA. Threshold concentration of ozone causing an increase in bronchial reactivity in humans and adaptation with repeated exposures. Am Rev Respir Dis 1981;124:245-8.

24 Linn WS, Jones MP, Bailey RM, Kleinman MT, Spier CE, Fischer DA, et al. Health effects of ozone exposure in asthmatics. Am Rev Respir Dis 1978;117:835-43.

25 Kreit JW, Gross KB, Moore TB, Lorenzen TJ, D'Arcy J, Eschenbacher WL. Ozone-induced changes in pulmonary function and bronchial responsiveness in asthmatics. $\mathcal{F}$ Appl Physiol 1989;66:217-22.
26 Jörres R, Nowak D, Magnussen $H$. Comparison of the effect of ozone on lung function and airway responsiveness in healthy subjects and subjects with rhinitis or bronchial asthma (abstract). Am Rev Respir Dis 1993, 147:A631

27 Kinney PL, Ware JH, Spengler JD, Dockery DW, Speizer FE, Ferris Jr, BG. Short-term pulmonary function change in association with ozone levels. Am Rev Respir Dis 1989;139:56-61.

28 Higgins ITT, D'Arcy JB, Gibbons DI, Avol EL, Gross KB. Effect of exposures to ambient ozone on ventilatory lung function in children. Am Rev Respir Dis 1990;141:1136-46.

29 Zwick H, Popp W, Wagner C, Reiser K, Schmöger J, Böck A, et al. Effects of ozone on the respiratory health, allergic sensitization and cellular immune system in children. Am Rev Respir Dis 1991;144:1075-9.

30 Castillejos M, Gold DR, Dockery D, Tostesan T, Baum T, Speizer FE Effects of ambient ozone on respiratory function and symptoms in Mexico City schoolchildren. Am Rev Respir Dis 1992;145:276-82.

31 Krämer U, Altus C, Behrendt H, Dolgner R, Gutsmuths JF, Hille J et al. Epidemiologische Untersuchungen zur Auswirkung der et al. Epidemiologische Untersuchungen zur Auswirkung der Luftverschmutzung auf die
Städte Hygiene 1992;43:82-7.

32 von Mutius E, Fritzsch C, Weiland SK, Röll G, Magnussen H Prevalence of asthma and allergic disorders among children in united Germany: a descriptive comparison. BMF 1992;305:1395-9.

33 Nowak D, Heinrich J, Beck E, Willenbrock U, Jörres R, Claussen M, et al. Differences in respiratory symptoms between two cities in Westerm and Eastern Germany: the first report in adults (abstract). Am Rev Respir Dis 1993;147:A378.

34 Burney P, Chinn S. Developing a new questionnaire for measuring the prevalence and distribution of asthma. Chest 1987;91(Suppl):79S-83S.

35 Riedel F, Krämer M, Scheibenbogen C, Rieger CHL. Effects of $\mathrm{SO}_{2}$ exposure on allergic sensitization in the guinea pig. $\mathcal{f}$ Allergy Clin Immunol 1988;82:527-34.

36 Klein K, Dathe R, Göllnitz S, Jäger L. Allergies-a comparison between two vocational schools in East and West Germany. Allergy 1992; 47(Suppl 12):259.

37 Warner JA. Environmental allergen exposure in homes and schools. Clin Exp Allergy 1992;22:1044-5.

38 Ishizaki T, Koizumi K, Ikemori R, Ishiyama Y, Kushibiki E. Studies of prevalence of Japanese cedar pollinosis among the residents in a densely cultivated area. Clin Allergy 1987;58:265-70.

39 Krämer U, Behrendt H, Dolgner R, Kainka-Stänicke E, Oberbarnscheid $\mathrm{J}$, Sidaoui $\mathrm{H}$, et al. Auswirkung der Umweltbelastung auf allergologische Parameter bei 6jährigen Kindern. In: Ring J, ed. Epidemiologie allergischer Erkrankungen. München: MMV Medizin Verlag, 1991:165-78.

40 Popp W, Zwick H, Steyres K, Rauscher H, Wanke T. Sensitization to aeroallergens depends on environmental factors. Allergy 1989;44:572-5.

41 Molfino NA, Wright SC, Katz J, Tarlo S, Silverman F, McClean PA, et al. Effect of low concentration of ozone on inhaled allergen responses in asthmatic subjects. Lancet 1991;338:199-203.

42 Bascom R, Naclerio RM, Fitzgerald TK, Kagey-Sobotka A, Proud D. Effect of ozone inhalation on the response to nasal challenge with antigen of allergic subjects. Am Rev Respir Dis 1990;142:594-601. 